\title{
Small Rodent Communities in the Tatra Mountain Forests ${ }^{1}$
}

\author{
Małgorzata JUCHIEWICZ, Maria ZEMANEK, Maria BIENIEK \\ \& Elżbieta SIUTA
}

\begin{abstract}
Juchiewicz M., Zemanek M., Bieniek B. \& Siuta E., 1986: Small rodent communities in the Tatra mountain forests. Acta theriol., 31, 32: 433-447 [With 4 Tables \& 2 Figs.]

There were studied two small rodent communities inhabiting the beech and spruce forests situated in the lower and upper mountain forest zones of the Tatras. The animals were trapped by means of the Standard Minimum method over a three-year period, making two censuses per year, in spring and autumn. Speqies composition and changes in numbers of these communities were determined and compared with other mountain and lowland communities of small rodents.

[Department of the Protection of Nature and Natural Resources, Polish Academy of Sciences, Lubicz 46, 31-512 Kraków, Poland].
\end{abstract}

\section{INTRODUCTION}

The alpine character of the Tatra environment affects the fauna of that area. It is manifested, among others, by the occurrence of animal forms typical of high mountains, morphological distinctness of individuals from mountain populations as well as by the different structure of animal communities. Although zoologists have been interested in the Tatra fauna for a long time, the knowledge on it is still unsatisfactory, particularly as regards small mammals (Kowalski, 1962; Głowaciński, 1984). The respective literature includes mainly faunistic and taxonomic studies concerning, for the most part, the southern area of the Tatras, i.e. their Solovak part (Hanzak \& Rosický, 1949; Rosický \& Kratochvíl, 1955; Zejda, 1955; Kratochvíl, 1956, 1968, 1981; Kowalski, 1957, 1960, 1962; Pelikán, 1962; Mošanský, 1974). There are very few studies describing small mammal populations and communities. Kratochvíl \& Gaisler (1967) investigated the succession of these animals in the particular phases of the development of the Sorbeto-Piceetum association, Zima et al. (1984) studied the composition of small mammal communities in some regions of the Tatras. The differences of the structure

${ }^{1}$ Praca wykonana $w$ ramach badań własnych C-1 w Zakładzie Ochrony Przyrody i Zasobów Naturalnych PAN w Krakowie.

[433; 
of small mammal communities resulting from the plant - climatic zonation of the area have not been hitherto studied; data on the density of small mammals in various habitats are also lacking.

The aim of the present paper is to supply some qualitative and quantitative data on two small rodent communities inhabiting the lower and upler mountain forest zones of the Tatras. There was shown the structure and variations in numbers of these communities as compared with those of other mountain and lowland ones.

\section{STUDY AREA, MATERIAL, AND METHODS}

Studies were carried out in the years 1981-1984. Small rodents were trapped twice a year: in spring (May, June), i.e. at the beginning of the breeding season, and in autumn (September, October), i.e. at the end of that period (Zejda, 1966).

Two study plots were established. One of them, representing the lower mountain forest zone, was situated on the slope of Wierch Spaleniec (West Tatras) exposed $\mathrm{NE}$ and inclined about $25^{\circ}$, at an altitude of about $1000 \mathrm{~m}$ a.s.l. That study plot was overgrown with a mature Carpathian beechwood (Fagetum carpaticum) of stand density ca. $80 \%$. In its herb layer there occurred Dentaria glandulosa, Oxalis acetosella, Dentaria bulbifera, Mercurialis perennis, Dryopteris filix-mas, Sanicula europaea, and - in the more humid sites - Petasites albus. The soil was of the brown leached type. The character of that study plot was fairly uniform; only a small part of the area, situated in the Spadowiec Valley bottom, was distinguished by a greater humidity and a richer herb layer.

The other trapping area was established in the upper mountain forest zone, at an altitude of about $1350 \mathrm{~m}$ a.s.l., on the slope of Żabi Wierch (High Tatras) exposed NW and inclined $10-15^{\circ}$. That area was overgrown with the alpine spruce forest (Piceetum tatricum). The plant cover of that study plot was not quite uniform. A mature spruce stand constituted the most part of the area; in its herb layer there occurred Luzula sylvatica, Homogyne alpina, Vaccinium myrtillus, Oxalis acetosella, Dryopteris austriaca, and Deschampsia flexuosa. About 25\% of the plot was a wind fall area overgrown with Rubus idaeus, Vaccinium myrtillus, and a new growth of Picea excelsa and Sorbus aucuparia. The soils were regozols and podzols.

Small rodents were trapped by means of the Standard Minimum method (Grodzinski, Pucek \& Ryszkowski, 1966) accepted for censusing these animals. According to that method the study plot constituted a quadrat $240 \times 240 \mathrm{~m}$ and an area of 5.76 ha. Within that quadrat there were 256 capture points placed at intervals of $15 \mathrm{~m}$. Each capture point 
was provided with one snap-trap (in the original method - two snaptraps) baited with a fried wick. Censuses lasted for $4-5$ days without previous prebaiting, according to the suggestions by Zejda \& Holišova (1970). After each census, weight and sex of the animals caught was determined.

To estimate the number of small rodents in the study plot (estimated catch size) from the data obtained using the Standard Minimum method (actual catch size) Zippin's method was applied (Zippin, 1956). In that method the probability of capture of an average animal is determined allowing to estimate the number of animals which have not been trapped, thus the number of all animals in the area. The density of small rodents per hectare was calculated taking into account the edge effect. Thus, the estimated catch size was related to the effectively trapped area which was determined at 7.3 ha in the beechwood and 6.5 ha in the spruce forest. The size of the effectively trapped area corresponded to that fixed by the grid of snap-traps increased by the boundary stripes of a width equal to one/half of the observed range length (ORL) of the dominant species, i.e. that of the bank vole and the yellow-necked mouse in the beechwood, and that of the bank vole in the spruce forest. ORL values given for lowland forrests were accepted, i.e. $40 \mathrm{~m}$ for male and $20 \mathrm{~m}$ for female bank voles, and $75 \mathrm{~m}$ for male and $50 \mathrm{~m}$ for female yellow-necked mice (Zejda \& Pelikán, 1969; Pelikán, Zejda \& Holišova, 1974). The statistical significance of differences in the numbers of small rodents in the beech and spruce forests was checked using the $\chi^{2}$ test.

For the two rodent communities under study some ecological indices were calculated, i.e. the dominance and constancy (Balogh, 1958) as well as the diversity (Shannon \& Weaver, 1949; Lloyd, Zar \& Karr, 1968). The dominance determining the share of a species in the community was expressed as the catch of a species in per cent of the total catch. The constancy describing the frequency of the occurrence of a species in samples, in per cent, was calculated as a proportion of the number of trappings in which the given species was found to that of all trappings. The species of a frequency between 75.1 and $100 \%$ were considered to be euconstant, those of $50.1-75.0 \%$ constant, those of 25.1 $-50.0 \%$ accessory, and those below 25.0\% accidentary (Balogh, 1958).

The diversity $H^{\prime}$ of the communities studied was calculated using Shannon's formula:

$$
H^{\prime}=-\sum_{i=1}^{S} p_{i} \log _{2} p_{i},
$$


where $\mathbf{S}$ is the number of species in the community, and $p_{i}$ is the fraction of specimens belonging to " $i$ " species.

The similarity of dominance of the two communities was determined using Renkonen's index (Re) (Renkonen, 1938). It was calculated by summing up the lesser dominance values of the species common to the communities compared.

The material obtained from trappings included, beside small rodents, also 51 animals of the Insectivora order belonging to the species: Sorex alpinus, S. araneus, S. minutus, and Neomys fodiens. Those animals were neglected at the processing of data because their catches were accidental. The trapping method applied was unsuitable for shrews ( $\mathrm{Pu}-$ cek, 1969).

\section{RESULTS}

During the 7 trapping series (from spring 1981 to spring 1984), in the study area situated in the beechwood of the lower mountain forest

Table 1

Catch numbers of the particular rodent species captured in the Tatra mountain forests. S - spring, A - autumn

a) beechwood in the lower mountain forest zone

\begin{tabular}{|c|c|c|c|c|c|c|c|c|c|}
\hline \multirow{2}{*}{ Species } & \multicolumn{2}{|c|}{1981} & \multicolumn{2}{|c|}{1982} & \multicolumn{2}{|c|}{1983} & \multicolumn{2}{|c|}{1984} & \multirow{2}{*}{$\begin{array}{c}\text { Constancy } \\
\text { in } \%\end{array}$} \\
\hline & $\mathrm{S}$ & A & $\mathrm{S}$ & A & $\mathrm{S}$ & A & $\mathrm{s}$ & Total & \\
\hline A. flavicollis & 2 & 49 & 3 & 2 & 6 & 37 & 8 & 107 & 100.0 \\
\hline C. glareolus & 2 & 28 & 4 & 3 & 1 & 63 & 5 & 106 & 100.0 \\
\hline M. avellanarius & 1 & - & 2 & - & - & - & 一 & 3 & 33.3 \\
\hline A. sylvaticus & - & - & - & - & 2 & 一 & 一 & 2 & 16.6 \\
\hline M. agrestis & - & - & 1 & - & - & - & - & 1 & 16.6 \\
\hline P. subterraneus & 一 & 一 & 一 & - & - & - & 1 & 1 & 16.6 \\
\hline \multirow{3}{*}{$\begin{array}{l}\text { Total actual } \\
\text { catch } \\
\text { Number of } \\
\text { species }\end{array}$} & $\mathbf{5}$ & 77 & 10 & 5 & 9 & 100 & 14 & 220 & \\
\hline & & & & & & & & & \\
\hline & 3 & 2 & 4 & 2 & 3 & 2 & 3 & 6 & \\
\hline
\end{tabular}

b) spruce forest in the upper mountain forest zone

\begin{tabular}{lrrrrrrrrr}
\hline Species & \multicolumn{2}{c}{ S } & A & S & A & S & A & Total & $\begin{array}{c}\text { Constancy } \\
\text { in } \%\end{array}$ \\
\hline C. glareolus & 16 & 34 & 3 & 17 & 23 & 24 & 117 & 100.0 \\
M. nivalis & & 9 & 1 & 6 & 1 & 2 & 2 & 21 & 100.0 \\
A. flavicollis & 2 & 6 & - & - & 3 & 3 & 14 & 66.6 \\
$M$. agrestis & - & - & 4 & - & 2 & 3 & 9 & 50.0 \\
$M$. avellanarius & - & - & - & - & 1 & - & 1 & 16.6 \\
$P$. tatricus & - & - & - & 1 & - & - & 1 & 16.6 \\
\hline Total actual catch & 27 & 41 & 13 & 19 & 31 & 32 & 163 & \\
Number of species & 3 & 3 & 3 & 3 & 5 & 4 & 6 & \\
\hline
\end{tabular}


zone there were caught 220 specimens belonging to 6 rodent species (Table 1). On the other hand, 6 censuses (from spring 1981 to autumn 1983) carried out in the spruce forest of the upper mountain forest zone yielded a total catch of 163 animals belonging also to 6 rodent species (Table 1). The per cent of traps occupied per one census (number of traps occupied per number of trap $\times$ days) was 2.5 on the average.

\subsection{Dominance}

In the small rodent community inhabiting the beechwood two species prevailed, namely: Apodemus flavicollis (Melchior, 1874) - 48.6\% and Clethrionomys glareolus (Schreber, 1780) - 48.2\%. The percentage of 4 other species was very low (Table 2, Fig. 1). The scarce number of

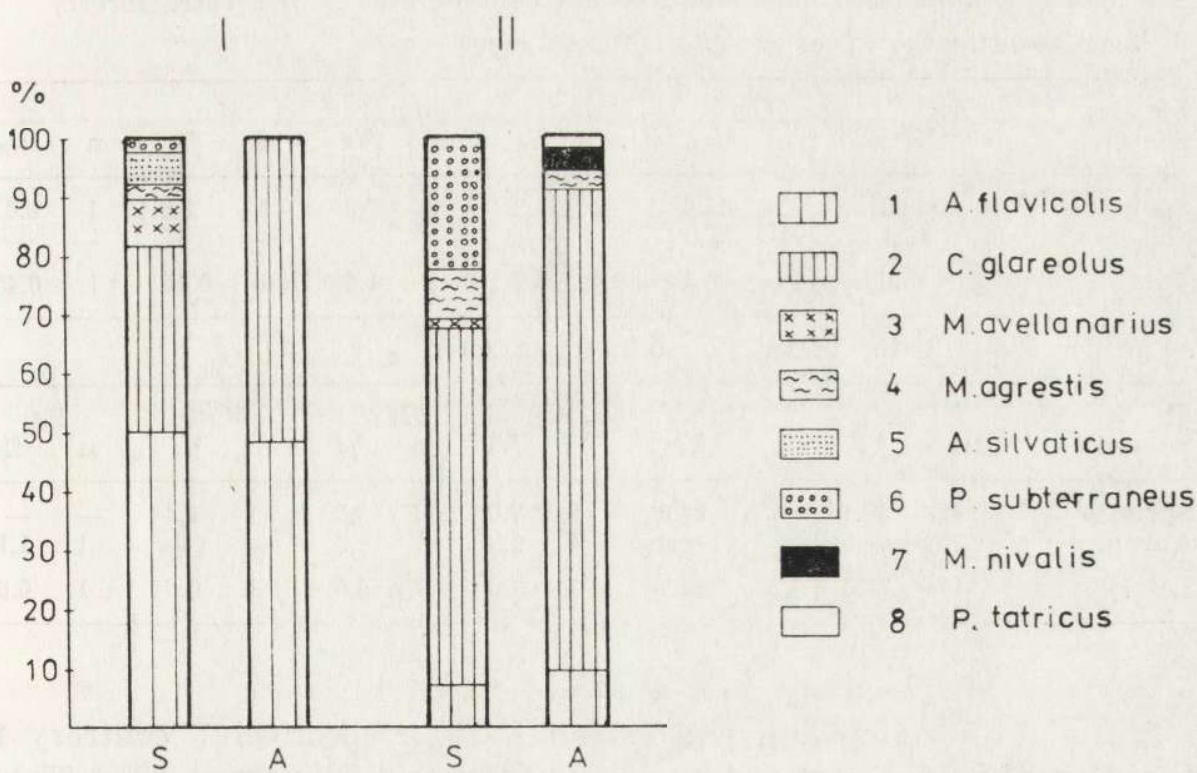

Fig. 1. Dominance of species (in percent) in the small rodent communities inhabiting the beechwood (I) of the lower mountain forest zone and the spruce forest (II) of the upper mountain forest zone in the Tatras depending on the season. $\mathrm{S}$ - Spring, A - Autumn.

specimens trapped during the particular census periods (except autumn 1981 and autumn 1983) did not allow to estimate the variability of the dominance indices. It was only possible to compare the dominance in spring with that in autumn (Table 2, Fig. 1). It has been found that in autumn the percentage of the bank vole $(51.6 \%)$ and of the yellow 
-necked mouse $(48.4 \%)$ was almost the same, while in spring the latter prevailed $(50.0 \%)$; the share of the bank vole was only $31.6 \%$. It is noteworthy that the occurrence of the other 4 species was recorded only in spring (Table 2, Fig. 1).

In the spruce forest of the upper mountain forest zone C. glareolus dominated pronouncedly - 71.8\% (Table 2, Fig. 1), followed by Microtus nivalis (Martins, 1842), A. flavicollis, and Microtus agrestis (Linnaeus, 1761). The share of Muscardinus avellanarius (Linnaeus, 1758) and Pitymys tatricus (Kratochvil, 1952) is insignificant (single specimens). The dominance of $C$. glareolus and $A$. flavicollis is higher in autumn than

Table 2

Species dominance in the small rodent communities in the Tatra forests a) beechwood in the lower mountain forest zone

\begin{tabular}{|c|c|c|c|c|c|c|c|c|c|c|c|c|}
\hline \multirow{2}{*}{$\begin{array}{l}\text { Species } \\
\text { Season }\end{array}$} & \multicolumn{2}{|c|}{ A.f. } & \multicolumn{2}{|c|}{ C.g. } & \multicolumn{2}{|c|}{ A.s. } & \multicolumn{2}{|c|}{ M.av. } & \multicolumn{2}{|c|}{ M.a. } & \multicolumn{2}{|c|}{ P.s. } \\
\hline & $\mathrm{n}$ & $\%$ & $\mathrm{n}$ & $\%$ & $\mathrm{n}$ & $\%$ & $\mathrm{n}$ & $\%$ & $\mathrm{n}$ & $\%$ & $\mathrm{n}$ & $\%$ \\
\hline Spring & $\begin{array}{l}19 \\
88\end{array}$ & $\begin{array}{l}50.0 \\
48.4\end{array}$ & 12 & $\begin{array}{l}31.6 \\
51.6\end{array}$ & 2 & 5.3 & 3 & 7.9 & 1 & 2.6 & 1 & 2.6 \\
\hline Total & 107 & 48.6 & 106 & 48.2 & 2 & 0.9 & 3 & 1.4 & 1 & 0.45 & 1 & 0.45 \\
\hline
\end{tabular}

b) spruce forest in the upper mountain forest zone

\begin{tabular}{lrrrrrrrrrrrr}
\hline $\begin{array}{l}\text { Species } \\
\text { Season }\end{array}$ & \multicolumn{2}{c}{ C.g. } & \multicolumn{2}{c}{ M.n. } & \multicolumn{2}{c}{ A.f. } & \multicolumn{2}{c}{ M.a. } & \multicolumn{2}{c}{ M.av. } & \multicolumn{2}{c}{ P.t. } \\
\hline Spring & 42 & 59.1 & 17 & 24.0 & 5 & 7.0 & 6 & 8.5 & 1 & 1.4 & - & - \\
Autumn & 75 & 81.5 & 4 & 4.3 & 9 & 9.8 & 3 & 3.3 & - & - & 1 & 1.1 \\
Total & 117 & 71.8 & 21 & 12.9 & 14 & 8.6 & 9 & 5.5 & 1 & 0.6 & 1 & 0.6 \\
\hline
\end{tabular}

in spring ( 81.5 and $59.1 \%$, and 9.8 and $7.0 \%$ respectively), contrary to $M$. nivalis and $M$. agrestis (4.3 versus $24.0 \%$, and 3.3 versus $8.5 \%$ ) (Table 2, Fig. 1). There was estimated the seasonal variability of the dominance of the species occurring the most numerously. The dominance of the bank vole oscillated between 59.2 and $89.0 \%$, and that of the snow vole between 2.5 and $33.0 \%$. The variability of dominance indices calculated for the particular years of studies was lower; the percentage of the bank vole changed from 62.5 to $74.6 \%$, and that of the snow vole from 6.4 to $21.9 \%$.

The similarity of the dominance of species in the two communities studied, determined by means of Renkonen's index (Re), is $60.2 \%$. It is accepted that Re values of $50-70 \%$ show great similarity of the communities compared (Tomiałojć, 1970). 


\subsection{Constancy}

In the beechwood, C. glareolus and A. flavicollis were found in all series of trappings (Table 1) so they may be considered as euconstant species (or absolutely constant ones). $M$. avellanarius may be described as an accessory species $(C=33.3 \%)$ and the other 3 species - as accidentary ones $(C=16.6 \%)$.

In the spruce forest, $C$. glareolus and $M$. nivalis were present in all trapping series (Table 1) and may be determined as euconstant or absolutely constant species. A. flavicollis belonged to constant elements. $M$. agrestis may be considered either constant or accessory $(C=50.0 \%)$. $M$. avellanarius and $P$. tatricus were accidentary species.

\subsection{Diversity}

The diversity $\left(H^{\prime}\right)$ of the small rodent community inhabiting the beechwood oscillated between 1.02 and 1.61 in the particular years (Table 3). For the whole period of studies it was 1.23. For the community living in the spruce forest that index changed from 1.09 to 1.40 , and calculated for the whole period of studies it amounted to 1.35. For both those communities the maximum values of $H^{\prime}$ were found in 1982 . In the community from the beechwood its diversity correlated positively and significantly with the number of species $S(r=0.95)$, while in the community from the spruce forest that correlation was hardly marked $(r=0.34)$.

\section{Table 3}

Species diversity $\left(H^{\prime}\right)$ of the small rodent communities in the Tatra mountain forests.

\begin{tabular}{ccc}
\hline Year & $\begin{array}{c}\text { Beechwood in the lower } \\
\text { mountain forest zone }\end{array}$ & $\begin{array}{c}\text { Spruce forest in the } \\
\text { upper mountain forest zone }\end{array}$ \\
\hline 1981 & 1.02 & 1.09 \\
1982 & 1.61 & 1.40 \\
1983 & 1.08 & 1.29 \\
\hline
\end{tabular}

\subsection{Density}

The best part of censuses made in the beechwood except those carried out in autumn 1981 and 1983 as well as the spring census made in the spruce forest in 1982 yielded total catches too low for computations. In the case of those censuses an actual catch was accepted as an estimated catch. To calculate the estimated catch from the results of other trappings Zippin's method was applied. The values obtained are shown in Table 4. The densities of small rodents are given both from the 
effectively trapped area, i.e. from 7.3 ha in the beechwood and from 6.5 ha in the spruce forest, and from the S-M plot, i.e. 5.76 ha, to enable the comparisons with the results of other studies carried out by means of the S-M method (Table 4, Fig. 2).

Table 4

Number of small rodents in the Tatra mountain forests a) beechwood in the lower mountain forest zone

\begin{tabular}{lccccccc}
\hline Density estimation & $\begin{array}{c}\text { Spring } \\
1981\end{array}$ & $\begin{array}{c}\text { Autumn } \\
1981\end{array}$ & $\begin{array}{c}\text { Spring } \\
1982\end{array}$ & $\begin{array}{c}\text { Autumn } \\
1982\end{array}$ & $\begin{array}{c}\text { Spring } \\
1983\end{array}$ & $\begin{array}{c}\text { Autumn } \\
1983\end{array}$ & $\begin{array}{c}\text { Spring } \\
1984\end{array}$ \\
\hline $\begin{array}{l}\text { Estimated catch } \\
\begin{array}{l}\text { Density } \\
\text { (individuals/ha) } \\
\text { from 7.3 ha }\end{array}\end{array}$ & 5 & 94 & 10 & 5 & 9 & 128 & 14 \\
$\begin{array}{l}\text { Density } \\
\text { (individuals/ha) } \\
\text { from } 5.76 \text { ha }\end{array}$ & 0.7 & 12.9 & 1.3 & 0.7 & 1.2 & 17.4 & 1.9 \\
\hline
\end{tabular}

b) spruce forest in the upper mountain forest zone

\begin{tabular}{|c|c|c|c|c|c|c|}
\hline Density estimation & $\begin{array}{l}\text { Spring } \\
1981\end{array}$ & $\begin{array}{l}\text { Autumn } \\
1981\end{array}$ & $\begin{array}{l}\text { Spring } \\
1982\end{array}$ & $\begin{array}{l}\text { Autumn } \\
1982\end{array}$ & $\begin{array}{l}\text { Spring } \\
1983\end{array}$ & $\begin{array}{l}\text { Autumn } \\
1983\end{array}$ \\
\hline $\begin{array}{l}\text { Estimated catch } \\
\text { Density }\end{array}$ & $26 *$ & 42 & 13 & 27 & $26 *$ & 40 \\
\hline (individuals/ha) & 4.0 & 6.5 & 2.0 & 4.1 & 4.0 & 6.1 \\
\hline $\begin{array}{l}\text { from } 6.5 \text { ha } \\
\text { Density } \\
\text { (individuals/ha) }\end{array}$ & 4.5 & 7.3 & & & & \\
\hline from 5.76 ha & 4.5 & 7.3 & 2.2 & 4.5 & 4.5 & 7.0 \\
\hline
\end{tabular}

* values extrapolated for May

During the whole study period the density of small rodents in the beechwood changed from 0.7 individuals per ha (spring 1981) to 17.4 (autumn 1983). In 1982 there was recorded an exceptionally low number of rodents - 1.0 individual per ha on the average. In the years 1981 and 1983 the mean density of rodents amounted to 6.8 and 9.3 individudls per ha.

In the spruce forest, the density of small rodents was less variable; it oscillated between 2.0 individuals per ha (spring 1982) and 6.5 (autumn 1981). The lowest mean density was also observed in 1982 (3.0 individuals per ha). In 1981 and 1983 there were recorded slightly higher values, 5.3 and 5.0 individuals per ha respectively.

The mean density of small rodents calculated for the whole period of studies was 5.15 individuals per ha in the beechwood and 4.4 in the spruce forest, this difference being statistically significant at the level 0.05 . 


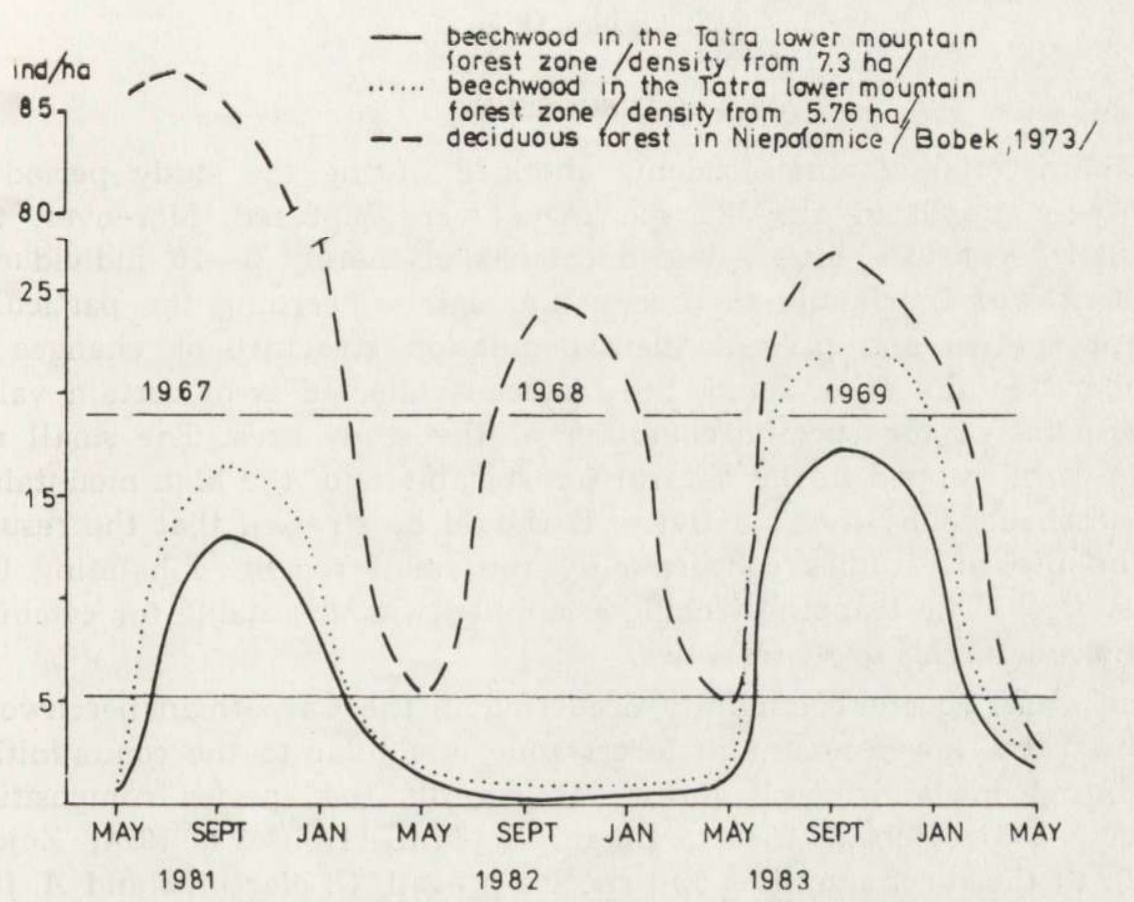

- highmontane coniferous forest in the Tatra upper mountain forest zone/densjty from 6,3 ha/he Tatra upper mountain forest zone/density trom 5.76 ha/

ind/ha - coniferous forest in Niepolomice / after Górecki, 1984/

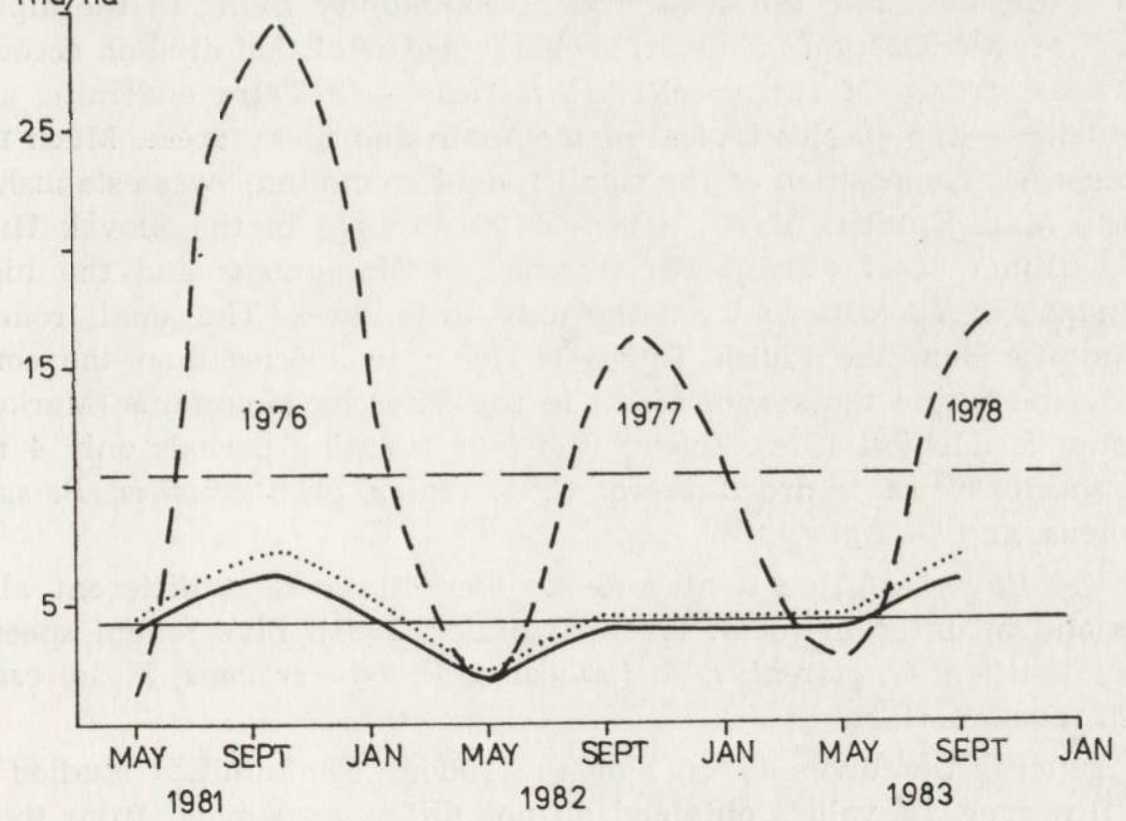

Fig. 2. Changes in the numbers of smali rodents in the beechwood of the lower mountain forest zone (upper part) and in the spruce forest of the upper mountain forest zone in the Tatras as compared with lowland forest (lower part). 


\section{DISCUSSION}

The material of small rodents obtained during the study period is relatively small; in all, 383 specimens were captured. Moreover, the particular censuses often yielded catches of merely 5-10 individuals. Thus, it was impossible to process the data concerning the particular rodent species and present their population structure or changes in number. On the other hand, the material collected is of certain value on account of the specific character of the study area. The small rodents were trapped in the natural forest habitats of the high mountains, still unchanged by man's activity. It should be stressed that the results of the present studies concern only the small rodents inhabiting the forest floor. The trapping technique applied was unsuitable for catching dormice, squirrels or water voles.

The small rodent community occurring in the Carpathian beechwood of the Tatra lower mountain forest zone is similar to the communities inhabiting lowland beech forests as regards the species composition (Aulak, 1967; Bobek, 1969; Pelikán, Zejda \& Holišova, 1974; Zejda 1976). In those communities two species prevail: C. glareolus and A. flavicollis, their share amounting to more than $90 \%$. A similar structure of the small rodent community was also described for the fir-beech nature reserve in the Kremnickie Mountains (Nedeljak, 1962).

On the other hand, the small rodent community living in the alpine spruce forest (Piceetum tatricum) is characteristic of that area on account of the occurrence of two species: P. tatricus - a Tatra endemite, and M. nivalis - the species typical of mountain and rocky areas. Much the same species composition of the small rodent community was established for the Mala Studena Valley (1600-1700 m a.s.1.) in the Slovak High Tatras (Zima et al., 1984). The absence of $M$. agrestis and the high dominance of $P$. tatricus were the only differences. The small rodent community from the Polish Tatras is richer in species than the community inhabiting the spruce forest in the Vitoscha Mountains (Markov, Christov \& Gliwicz, 1972). During the four trapping periods only 4 rodent species were recorded there: C. glareolus, A. flavicollis, P. subterraneus, and Glis glis.

In the Bavarian Alps small rodents were trapped at different altitudes and in different forest types (Baümler, 1981). Five rodent species were identified: C. glareolus, A. flavicollis, P. subterraneus, M. agrestis, and $M$. avellanarius.

In general the diversity $\left(H^{\prime}\right)$ of the rodent communities studied is low. However, $H^{\prime}$ values obtained do not differ very much from those established for similar communities inhabiting other mountains and lowland areas. For example, $H^{\prime}$ calculated for the small mammal sy- 
nusy living in a lowland forest belonging to the forest type group of Ulmi-Fraxineta carpini oscillated between 0.50 and 1.43 (Zejda, 1976). Slightly higher values of $H^{\prime}(1.41-2.02)$ were obtained by Zima et al. (1984) for small mammal communities from different regions of the Tatras. However, these authors investigated the communities inhabiting whole physiographic units (eg. mountain valleys) including various habitats; moreover, they took into account not only small rodents but also shrews.

It is noteworthy that the diversity of the two communities studied seems to be negatively correlated with their number. The highest $H^{\prime}$ values were established in 1982 when the density of rodents was lowest: Moreover, in the case of the community living in the beechwood, showing higher oscillations in number, the accessory species were recorded only in spring when the rodent density was very low. If that phenomenon is not quite accidental we may suppose that the dominant species, when they occur numerously, may "drive out" the accessory or accidentary ones. It is possible that the dominants appearing in low numbers occupy only the most favourable microhabitats. Then the probability of capture of the accidentary species is higher because of the greater number of non-occupied traps. On the other hand, when the density of dominants is high they live in both more and less favourable microhabitats, occupying the area more uniformly. Then, they may block the great number of traps reducing the probability of the other species to be trapped.

The two small rodent communities under study were similar as regards their species dominance, which was evidenced by a relatively high value of Renkonen's index $(60 \%)$, but they differed in their numbers. The density of small rodents in the beechwood was slightly but significantly higher than in the spruce forest. This confirms the observations of other authors (Ryszkowski, 1971) that coniferous forests are distinguished by lower numbers of rodents than mixed or deciduous ones. It is connected with such habitat characters as humidity, density of the herb layer, and food abundance. On the other hand, the course of changes in number is similar in the two communities (Fig. 2). During the three-year period, the densities of small rodents changed from high, through low to high ones again. The amplitude of these changes was much higher in the community inhabiting the beechwood. There were observed even 25 -fold differences, while in the community from the spruce forest the highest density exceeded the lowest only about 3 times. This might have been connected with the variable food base in the beechwood. The rich seed production occurring repeatedly may stimulate the increase of the rodent number favouring their better 
survival in winter. The authors observed a rich seed yield in autumn 1982. It resulted in the high density of rodents the following year. The rich seed fall of the spruce may also favour the mass appearance of small rodents (Baümler, 1981) but such a phenomenon was not recorded in the course of the present study.

As compared with various types of lowland forests, the density of small rodents in the two forest habitats investigated is low (5.15 and 4.40 individuals per ha on the average) much like the amplitude of its oscillations. For example, in the Niepolomice Forest the density of small rodents estimated both in its deciduous and coniferous parts amounted to 19.0 and 10.3 individuals per ha (Górecki, 1984), see Fig. 2. In the beechwood of the Ojców National Park the density of the dominant species, i.e. C. glareolus and A. flavicollis, constituting $98 \%$ of the whole small rodent community (similarly as in the Tatra beechwood) oscillated between 8 and 27 individuals per ha during the three-year period (Bobek, 1969). The density of small rodents in the Moravian forests ( $F a-$ getum typicum) was established at about 20 individuals per ha on the average (Pelikán, Zejda \& Holišova, 1974). In the Querco-Carpinetum medioeuropaeum association the density of small rodents was estimated at 31.2 individuals per ha in spring and 66.8 in autumn (Grodziński, Pucek \& Rysszkowki, 1966). However, these values were calculated ignoring the edge effect.

Few studies have been hitherto carried out on the small rodent densities in mountain areas. In the Vitoscha Mountains (Bulgaria), in the coniferous forest (Piceetum myrtilletosum), at an altitude corresponding to the Tatra upper mountain forest zone, the density of C. glareolus pirinus was 7-9 individuals per ha in spring and 22-29 in autumn (Markov, Christov \& Gliwicz, 1972). These values are considerably higher as compared with those from the Tatra forests but they were calculated considering also a "non-trappable" part of the bank vole population.

On the meadows covering the top parts of the Bieszczady Mountains the small rodent density was evaluated at 15 individuals per ha (Grodziński, Górecki, Janas \& Migula, 1966). In the Bavarian Alps (Baümler, 1981) small rodents were trapped on trap lines, so their density was not calculated. However, it is possible to compare the course of changes in the abundance of rodents in the Tatra and Alpine forests. In the latter, the amplitude of oscillations in number was much higher. There were observed $30-40$-fold differences. During the four-year study there was observed the progradation, gradation and retrogradation (lasting 2 years) of two rodent species: C. glareolus and A. flavicollis. The mass appearance of rodents was considered to be a result of a rich seed production of beech and spruce. 
Small rodents, when occurring numerously, may endanger forest habitats (Postner, 1960; Hansson, 1974; Hansson \& Zejda, 1977; Myllymäki, 1977). However, during the whole period of studies in the Tatra forests no gradation of these animals was observed; even their relatively high density in the beechwood in autumn 1983 was insignificant as compared with the data known from lowland forests. Moreover, the present studies were carried out in mature stands, and in such stands the impact of rodents is negligible (Golley, Ryszkowski \& Sokur, 1975) contrary to forest plantations. The significance of small rodents in forest ecosystems as seed consumers is marked at their densities exceeding 15 individuals per ha. The densities established in the Tatras were, as a rule, much lower, hence the small rodents ought not to delay the process of forest renovation.

Acknowledgements: The authors thank Dr. Z. Głowaciński and Dr. A. Górecki for valuable comments on the manuscript. They are also grateful to Eng. L. Niedzielski, Director of the Tatra National Park, for enabling them to carry out these studies.

\section{REFERENCES}

1. Aulak W., 1967: Estimation of small mammal density in three forest biotopes. Ekol. pol. 3, 15: 755-778.

2. Balogh J., 1958: Lebensgemeinschafter der Landtiere. Akademie-Verlag: $1-560$, Budapest-Berlin.

3. Baümler W., 1981: Zur Verbreitung, Ernährung und Populationsdynamik der Rötelmaus (Clethrionomys glareolus) und der Gelbhalsmaus (Apodemus flavicollis) in einem Waldgebiet der Bayerischen Alpen. Anz. Schädlingskde., Pflanzenschutz, Umweltsihutz 54: 49-53.

4. Bobek B., 1969: Survival, turnover and production of small rodents in a beech forest. Acta theriol., 14: $191-210$.

5. Głowaciński Z., 1984: Badania zoologiczne w Tatrzańskim Parku Narodowym. Parki Nar. i Rez. Przyr., 5: 79-97.

6. Golley F. B., Ryszkowski L. \& Sokur J. T., 1975: The role of mammals in temperate forests, grasslands and cultivated fields. [In: "Small mammals: their productivity and population dynamics". Eds. F. B. Golley, K. Petrusewicz \& L. Ryszkowski]. Cambr. Univ. Press: 223-241, Cambridge.

7. Górecki A., 1984: Energy and matter flow through rodents. [In: "Forest ecosystems in industrial regions". Eds. W. Grodziński, J. Weiner \& P. F. Maycock]. Springer-Verlag: 113-120, Berlin, Heidelberg, New York, Tokio.

8. Grodziński W., Górecki A., Janas K. \& Migula P., 1966: Effect of rodents on the primary productivity of alpine meadows in Bieszczady Mountains. Acta theriol., 11: 419-431.

9. Grodziński W., Pucek Z. \& Ryszkowski L., 1966: Estimation of rodent numbers by means of prebaiting and intensive removal. Acta theriol., 11: 297-314 .

10. Hansson L., 1974: Small mammal productivity and consumption in spruce forest and reforestation in South Sweden. Oikos, 26: 398-404. 
11. Hansson L. \& Zejda J., 1977: Plant damage by bank voles (Clethrionomys glareolus Schreber) and related species in Europe. EPPO Bull., 7: 223-242.

12. Hanzak J. \& Rosický B., 1949: Nove poznatky o nekterych zastupcich rodu Insectivora a Rodentia na Slevensku. Acta Mus. Nat. Pragae, 5: $1-86$.

13. Kowalski K., 1957: Microtus nivalis (Martins, 1842) (Rodentia) in the Carpathians. Acta theriol., 1: 159-182.

14. Kowalski K., 1960: Pitymys McMurtrie 1831 (Microtidae, Rodentia) in the Northern Carpathians. Acta theriol., 4: 81-94.

15. Kowalski K., 1962: Ssaki. [In: „Tatrzański Park Narodowy. Ed. W. Szafer). ZOP PAN Kraków: 365-388, Kraków.

16. Kratochvíl J., 1956: Hraboš šnežný tatranský Microtus (Chionomys) nivalis mirhanreini Schaefer, 1935. Acta Acad. Sc. Cechoslov., Brno, 28: 1-39.

17. Kratochvíl J., 1968: Antritt des Vermehrungsprozesses der kleinen Erdsäugetiere in der Hohen Tatra. Zool. Listy, 17: 299-310.

18. Kratochvíl J., 1981. Chionomys nivalis (Arvicolidae, Rodentia). Acta Sc. Nat. Brno, 15: 1-62.

19. Kratochvíl J. \& Gaisler J., 1967: Die Sukzession der Kleinen Erdsäugetiere in einem Bergwald Sorbeto-Piceetum. Zool. Listy, 16: 301-324.

20. Lloyd M., Zar J. H. \& Karr J. R., 1968: On the calculation of information-theoretical measure of diversity. Am. Midl. Naturalist, 79: 257-272.

21. Markov G., Christov L. \& Gliwicz J., 1972: A population of Clethrionomys glareolus pirinus on the Vitoscha Mountain, Bulgaria. I. Variations in numbers and age structure. Acta theriol., 17: 327-335.

22. Mošanský A., 1974: Mammalia. Sb. Prác o TANAP-u, 16: 267-308.

23. Myllymäki A., 1977: Outbreaks and damage by the field vole, Microtus agrestis (L.) in Europe since World War II. EPPO Bull., 7: 177-207.

24. Nedeljak F., 1962: Drobné cicavce Badinskeho pralesa. Biol. Bratislava, 17: $130-141$.

25. Pelikán J., 1962: K faunistice drobných ssavcu Tatranského narodného parku. Zool. Listy, 11: 190-192.

26. Pelikán J., Zejda J. \& Holišova V., 1974: Standing crop estimates of small mammals in Moravian forests. Zool. Listy, 23: 197-216.

27. Postner M., 1960: Ungewöhnlich starke Nageschäden der Rötelmaus, Clethrionomys glareolus Schreb. (Muridae, Mammalia) and Jungflichten. Anz. Schädlisk., 33: 135-137.

28. Pucek Z., 1969: Trap response and estimation of numbers of shrews in removal catches. Acta theriol., 14: 403-426.

29. Renkonen O., 1938: Statistisch-ökologische Untersuchungen über die terrestrische Käferwelt der Finnischen Bruchmoore. Ann. Zool. Bet. fenn. Vnamo, Helsinki, 6: 1-226.

30. Rosický B. \& Kratochvil J., 1955: Drobní ssavci Tatranského národnĭho parku. Ochr. Přir., Praha, 10: $34-47$.

31. Ryszkowski L., 1971: Reproduction of bank voles and survival of juveniles in different pine forest ecosystems. Ann. zool. fenn., 8: 85-91.

32. Shannon C. E. \& Weaver W., 1949: The mathematical theory of communication. Univ. Illinois Press. Urbana.

33. Tomiałojć L., 1970: Badania ilościowe nad synantropijną awifauną Legnicy i okolic. Acta orn., 12: 293-392.

34. Zejda J., 1955: Razbor jarni populace nornika rudeho (Clethrionomys gla- 
reolus) v Tatranskom Narodnim Parku v r. 1955. Zool. entom. Listy, 4: $313-328$.

35. Zejda J., 1966: Litter size in Clethrionomys glareolus Schreber 1780. Zool. Listy, 15: $193-206$.

36. Zejda J., 1976: The small mammal community of a lowland forest. Acta Sc. Nat. Brno, 10: 1-39.

37. Zejda J. \& Pelikén J., 1969: Movement and home range of some rodents in lowland forest. Zool. Listy, 18: 143-162.

38. Zejda J. \& Holišova V., 1970: On the prebaiting of small mammals in the estimation of their abundance. Zool. Listy, 19: 103-118.

39. Zima J., Hrabě V., Sterba O. \& Schlamp M., 1984: Drobní ssavci Kotliny Sedmich Pramenŏv v Belianských Tatrách Sbor. Prac o TANAP-u, 25: 29-46.

40. Zippin C., 1956: An evaluation of the removal method of estimating animals population. Biometrics, 12: 163-189.

Accepted, May 5, 1986.

Małgorzata JUCHIEWICZ, Maria ZEMANEK, Maria BIENIEK i Elżbieta SIUTA

\section{ZESPOEY DROBNYCH GRYZONI W TATRZANSSICH LASACH REGLOWYCH}

\section{Streszczenie}

W latach 1981-1984 w Tatrach badano zespoły drobnych gryzoni zamieszkujące strefę regla dolnego (buczyna karpacka) i regla górnego (bór świekowy). Zwierzęta odławiano metodą Standard-Minimum. Przedstawiono charakterystykę strukturalną obu zespołów podając wskaźniki dominacji, stałości, podobieństwa, różnorodności, równomierności oraz zagęszczenie.

W buczynie regla dolnego stwierdzono występowanie 6 gatunków gryzoni (Tabela 1), a dominowały tam mysz leśna $(48,6 \%)$ i nornica ruda $(48,2 \%)$. W świerczynie regla górnego odłowiono także 6 gatunków gryzoni (Tabela 1), a zdecydowanym dominantem byla tam nornica ruda $(71,8 \%)$. Dla obu zespołów zaobserwowano różnice $\mathrm{w}$ składzie gatunkowym na wiosnę i jesienią (Tabela 2, Ryc. 1). Oba zespoly wykazują dość duże podobieństwo struktury gatunkowej, o czym świadczy stosunkowo wysoka wartość wskaźnika Renkonena $(60 \%)$. W zespole dolnoreglowym za elementy absolutnie stałe można uważać mysz leśną i nornice rudą, a w zespole górnoreglowym nornicę rudą i polnika śnieżnego (Tabela 1).

Różnorodność $\left(H^{\prime}\right)$ badanych zespolów gryzoni jest niska. W zespole dolnoreglowym $\mathrm{H}^{\prime}$ waha się od 1,02 do 1,61 , a w górnoreglowym - od 1,09 do 1,40 (Tabela 3). Podane wartości nie różnią się jednak zasadniczo od tych jakie charakteryzują zespoły gryzoni $\mathrm{z}$ innych terenów górskich i nizinnych.

W badanym okresie zagęszczenie gryzoni w buczynie regla dolnego zmieniało się od 0,7 os/ha (wiosna 1981) do 17,4 os/ha (jesień 1983), średnio wynosiło 5,15 os/ha (Tabela 4, Ryc. 2). W reglu górnym zagęszczenie tych zwierząt ulegało dużo mniejszym wahaniom: od 2 os/ha (wiosna 1982) do 6,5 os/ha (jesień 1981). Srednie zagęszczenie z 3 lat było 4,4 os/ha (Tabela 4, Ryc. 2).

Porównano skład i liczebność tatrzańskich zespołów gryzoni z zespołami nizinnymi oraz zespołami innych terenów górskich. Generalnie, zagęszczenie gryzoni w tatrzańskich lasach jest niskie, a wahania liczebności niewielkie w zestawieniu z różnymi typami lasów nizinnych. 